\title{
Leavin' a Testimony
}

Focus on American History Series

Center for American History

University of Texas at Austin

Don Carleton, Editor 


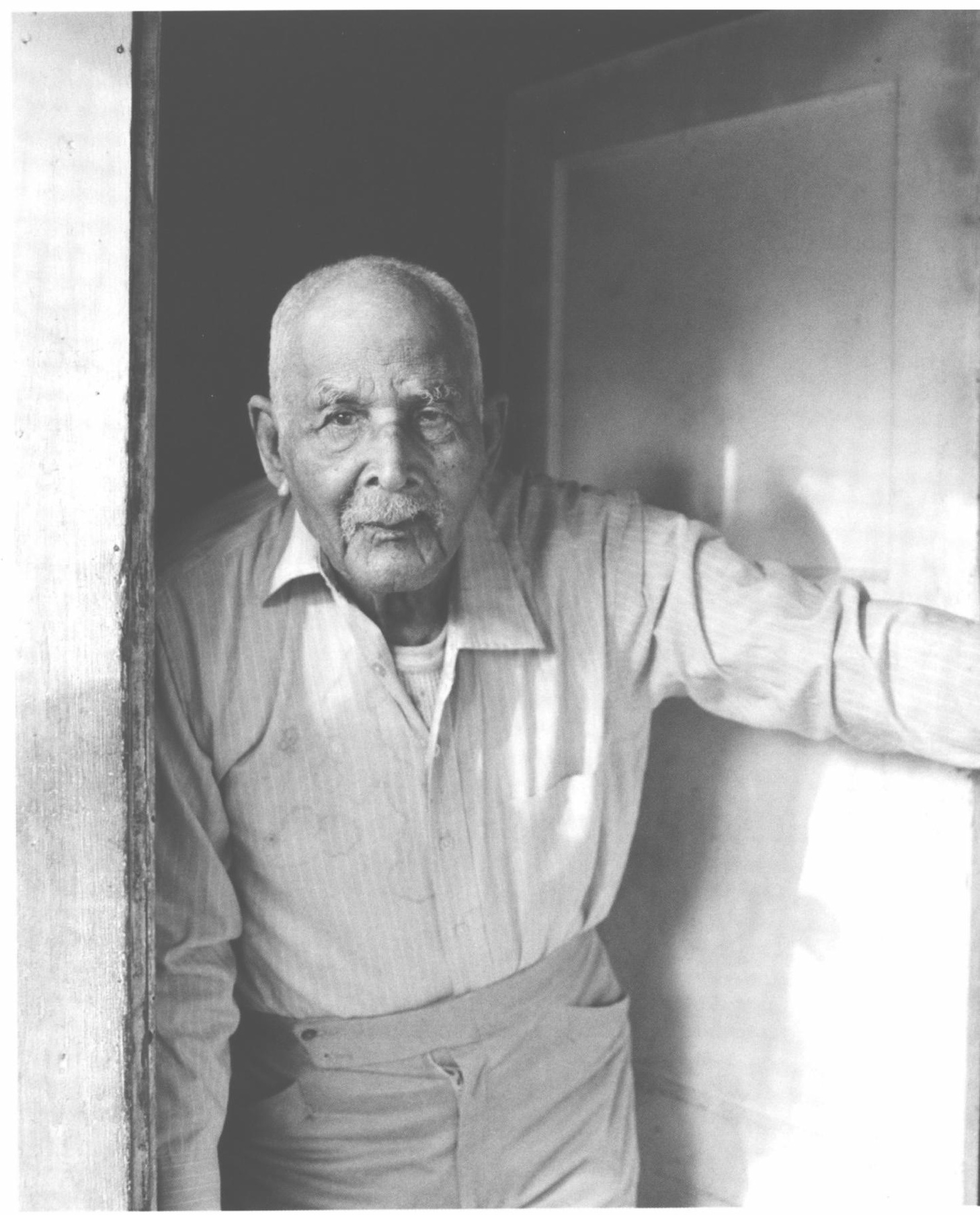




\section{Leavin' a Testimony Portraits from Rural Texas}

\section{by Patsy Cravens}

Foreword by John B. Boles Afterword by Bob Patten

4 University of Texas Press, Austin 
Publication of this book was aided

by the generous support of the

University of Texas Advisory Council.

Copyright $\odot 2006$

by Patsy Cravens

All rights reserved

Printed in China

First edition, 2006

Requests for permission to reproduce material

from this work should be sent to:

Permissions

University of Texas Press

P.0. Box 7819

Austin, TX 78713-7819

www.utexas.edu/utpress/about/bpermission.html

\section{Library of Congress Cataloging-in-Publication Data}

Cravens, Patsy

Leavin' a testimony : portraits from rural Texas /

by Patsy Cravens ; foreword by. John B. Boles ;

afterword by Bob Patten.- 1st ed.

p. cm. - (Focus on American history series)

ISBN-13: 978-0-292-71305-5 (cl. : alk. paper)

ISBN-10: 0-292-71305-3 (cl. : alk. paper)

1. Colorado County (Tex.)-History. 2. Colorado County (Tex.)-

History-Pictorial works. 3. Colorado County (Tex.)-Social conditions.

4. Colorado County (Tex.)-Social conditions-Pictorial works.

5. Oral history-Texas-Colorado County. 6. Colorado County (Tex.)-

Biography. I. Title: Leavin' a testimony. II. Title. III. Series.

F392.C58.C73 2006

976.4'253-dc22

2005037094

ISBN 978-0-292-75991-6 (library e-book)

ISBN 978-0-292-78967-8 (individual e-book) 
I want to dedicate this work with great love and affection to my first grandchild, Johnny Arcidiacono, who was with us from 1985 till '98, a boy with a big heart, loved by all who knew him. His generous spirit was evident when he said pensively of his great-grandmother after she died, "Meme's so lucky-she's gonna get to heaven and meet Martin Luther King before I do." None of us knew then how quickly Johnny would follow her. He was a child with a rare sense of love, wisdom, and gentleness, like an old soul. We miss him. 
And I'm preparin' every day for a better home. . . . And I'm proud to tell what I know because one of these days I will go to a new home. And when I go, I want to leave a testimony, and that is that I've done my best.

Rosezena Woodson 